\title{
UPAYA KETERLAMBATAN NOON REPORT KAPAL MT. CIPTA ANYER PADA PT. CIPTA SAMUDERA SHIPPING LINE
}

\author{
Nur Rohmah $^{1 *}$, Vega F. Andromeda ${ }^{2}$, Hayatussakinatuddarain ${ }^{3}$ \\ ${ }^{1,3}$ Program Studi Ketatalaksanaan Angkutan Laut dan Kepelabuhanan, Politeknik Ilmu Pelayaran \\ Semarang. Jl. Singosari Raya No.2A, Wonodri, Semarang Selatan, Semarang. \\ Program Studi Teknika, Politeknik Ilmu Pelayaran Semarang. \\ Jl. Singosari Raya No.2A, Wonodri, Semarang Selatan, Semarang. \\ "Email: hayatussakina620@gmail.com
}

\begin{abstract}
Abstrak
Tujuan penelitian ini adalah untuk mengetahui penyebab terjadinya keterlambatan noon report kapal MT. Cipta Anyer pada PT. Cipta Samudera Shipping Line Surabaya, untuk mengidentifikasi dampak yang di timbulkan akibat keterlambatan noon report kapal MT. Cipta Anyer dan untuk mengetahui upaya yang dapat dilakukan guna mengatasi keterlambatan noon report kepada PT. Cipta Samudera Shipping Line Surabaya. Peneliti menggunakan metode deskriptif kualitatif untuk menjabarkan pembahasan mengenai keterlambatan pengiriman noon report MT. Cipta Anyer pada PT. Cipta Samudera Shipping Line.Metode kualitatif adalah suatu penelitian yang ditujukan untuk mendeskripsikan dan menganalisa fenomena, peristiwa, aktivitas sosial, sikap, kepercayaan, presepsi, pemikiran orang secara individual maupun kelompok. Sumber data penelitian adalah data primer dan data sekunder. Hasil dari penilitian ini adalah penyebab keterlambatan noon report kapal MT. Cipta Anyer pada PT. Cipta Samudera Shipping Line ialah tidak adanya SOP yang mengatur secara detail tentang noon report, pengiriman noon report melebihi batas waktu yang telah ditentukan, dan koneksi internet yang tidak stabil. Dampak yang ditimbulkan akibat keterlambatan noon report kapal lain adalah menghambat kinerja staff finance, kinerja perusahaan menjadi tidak optimal,dan menyebabkan kerja extra terhadap perwira yang bertanggung jawab dalam pengiriman noon report. Upaya yang harus dilakukan guna mengatasi keterlambatan noon report kapal adalah memberikan trainning mengenai pengiriman noon report untuk menghindari keterlambatan, melakukan evaluasi antara staff perusahaan dengan anak buah kapal terkait keterlambatan noon report, dan menyediakan koneksi internet yang memadai.
\end{abstract}

Kata Kunci: Kpal, Keterlambatan, dan Noon report

\section{PENDAHULUAN}

Dalam pelayaran, dikenal istilah noon report. Noon report yaitu lembar data yang telah disiapkan setiap hari oleh Mualim dua diatas kapal. Noon report merupakan laporan yang memberi informasi mengenai posisi kapal dan data standar lainnya yang relevan untuk menilai kinerja kapal berdasarkan kecepatan dan kekuatan lingkungannya termasuk kondisi cuaca(Sailor, n.d.). Noon report juga digunakan oleh manager kapal untuk menilai perbedaan kinerja kapal atau antara dua jenis kapal yang serupa untuk menguraikan solusi kinerja yang kurang baik atau kemungkinan bermasalah (Sailor, n.d.). Mualim dua bertanggung jawab untuk menyiapkan noon report dan dikirim oleh
Nahkoda ke perusahaan serta manajemen yang berada di darat pada waktu yang sudah ditetapkan. Mualim dua dibantu oleh petugas deck dalam menyediakan data yang diperlukan untuk menyelesaikan laporan, setelah itu Nahkoda bertanggung jawab untuk memastikan bahwa noon report dikirimkan kepada perusahaan dengan benar dan tepat waktu (Suprapto, 2019).

Noon report kapal memuat informasi mengenai lokasi kapal, pelabuhan asal, pelabuhan yang dituju, daily activity, kondisi kapal, cuaca, Time Departure (TD) atau yang di sebut waktu pemberangkatan kapal, dan Estimate Time Arrival (ETA) atau waktu kapal tiba (Noon, Kapal, Xx, \& Prasetyawati, 2019). Informasi mengenai ETA sangat penting bagi agen kapal untuk 
membooking pilot di atas kapal serta dermaga yang akan digunakan, selain itu ETA juga digunakan untuk proses ke imigrasian jika kapal berlayar antar negara serta untuk laporan harian kepada kantor atau perusahaan saat kapal itu berlayar. Noon report dapat digunakan sebagai acuan untuk perhitungan komponen biaya yang di keluarkan oleh kapal, keterlambatan pengiriman noon report bisa menunda staff manajemen darat dalam melakukan perhitungan komponen biaya dan hal tersebut bisa menyebabkan kerugian terhadap biaya operasional. Karakteristik permasalahan dalam transportasi ini dikategorikan kedalam vehicle routing problem (VRP) (Noon et al., 2019).

Mengacu pada fakta dan rumusan masalah penelitian, tujuan yang akan dicapai dalam penelitian dengan judul "Analisis Keterlambatan Noon Report Kapal MT. Cipta Anyer pada PT. Cipta Samudera Shipping Line Surabaya” adalah sebagai berikut: 1). Untuk mengetahui penyebab terjadinya keterlambatan noon report kapal MT. Cipta Anyer pada PT. Cipta Samudera Shipping Line Surabaya, 2). Untuk mengidentifikasi dampak yang di timbulkan akibat keterlambatan noon report kapal MT. Cipta Anyer, dan 3) Untuk mengetahui upaya yang dapat dilakukan guna mengatasi keterlambatan noon report kepada PT. Cipta Samudera Shipping Line Surabaya.

\section{LANDASAN TEORI Upaya}

Upaya menurut kamus besar bahasa Indonesia ( KBBI) diartikan sebagai usaha kegiatan yang mengarahkan tenaga, pikiran untuk mencapai suatu tujuan. Upaya juga berarti usaha, akal, ikhtiar untuk mencapai suatu maksud, memecahkan persoalan mencari jalan keluar. Dari pengertian tersebut dapat diambil garis besar bahwa upaya adalah sesuatu hal yang dilakukan seseorang dalam mencapai suatu tujuan tertentu.

Sedangkan menurut (Oktavia, 2013) upaya preventif adalah sebuah usaha yang dilakukan individu dalam mencegah terjadinya sesuatu yang tidak diinginkan. Preventif secara etimologi berasal dari bahasa latin pravenire yang artinya datang sebelum/antisipasi/mencegah untuk tidak terjadi sesuatu. Dalam pengertian yang luas preventif diartikan sebagai upaya secara sengaja dilakukan untuk mencegah terjadinyan gangguan, kerusakan, atau kerugian bagi seseorang (Okvita, 2013).

Dengan demikian berdasarkan pengertian diatas dapat diperjelas upaya adalah bagian dari peranan yang harus dilakukan oleh seseorang untuk mencapai tujuan tertentu yaitu suatu kegiatan usaha, tindakan, pikiran dalam suatu tujuan untuk menanggulangi atau mencegah ataupun mencari jalan keluar dari terjadinya gangguan keuangan atau kerugian yang mungkin akan terjadi di perusahan PT. Cipta Samudera Shipping Line itu sendiri.

\section{Keterlambatan}

Keterlambatan menurut Ervianto (2005) adalah sebagai waktu pelaksanaan yang tidak dimanfaatkan sesuai dengan rencana kegiatan sehingga menyebabkan satu aatu beberapa kegiatan mengikuti menjadi tertunda atau tidak diselesaikan tepat waktu sesuai jadwal yang telah direncanakan. Kemudian dari waktu yang tidak dimanfaatkan tersebut akan menyebabkan satu hingga beberapa macam bentuk dari kegiatan yang bersamaan akan menjadi semakin tertunda atau tidak akan dapat dilaksanakan dengan sebuah waktu yang tepat dan juga sesuai dengan jadwal yang sebelumnya telah dipersiapkan dan direncanakan itu sendiri. Hal ini akan berdampak pada perencanaan semula serta pada masalah keuangan (Ervianto, 2005). Dengan pengertian demikian, keterlambatan adalah melakukan suatu kegiatan lewat waktu yang sudah ditentukan. Pengiriman noon report MT.Cipta Anyer pada PT. Cipta Samudera Shipping Line sering mengalami lewat dari waktu yang sudah ditentukan oleh perusahaan.

\section{Noon report}


Noon report adalah lembar data yang disiapkan oleh Mualim dua kapal setiap hari. Laporan ini memberikan posisi kapal dan data standar lainnya yang relevan untuk menilai kinerja kapal berdasarkan kecepatan dan kekuatan lingkungannya termasuk kondisi cuaca. Noon report juga digunakan oleh manajer kapal untuk menilai perbedaan kinerja kapal atau antara dua jenis kapal yang serupa (kapal saudara) untuk menguraikan solusi untuk kinerja yang kurang baik atau kemungkinan masalah. Noon report adalah lembar data yang telah disiapkan setiap hari oleh Mualim dua di atas kapal. Noon report merupakan laporan yang memberi informasi mengenai posisi kapal dan data standar lainnya yang relevan untuk menilai kinerja kapal berdasarkan kecepatan dan kekuatan lingkungannya termasuk kondisi cuaca.

Noon report kapal memuat informasi mengenai lokasi kapal, pelabuhan asal, pelabuhan yang dituju, daily activity, kondisi kapal, cuaca, Time Departure (TD) atau yang di sebut waktu pemberangkatan kapal, dan Estimate Time Arrival (ETA) atau waktu kapal tiba. Informasi mengenai ETA sangat penting bagi agent kapal untuk membooking pilot di atas kapal serta dermaga yang akan digunakan, selain itu ETA juga digunakan untuk proses ke imigrasian jika kapal berlayar antar negara serta untuk laporan harian kepada kantor atau perusahaan saat kapal itu berlayar (Noon et al., 2019). Noon report dapat digunakan sebagai acuan untuk perhitungan komponen biaya yang di keluarkan oleh kapal, keterlambatan pengiriman noon report bisa menunda staff manajemen darat dalam melakukan perhitungan komponen biaya dan hal tersebut bisa menyebabkan kerugian terhadap biaya operasional. Karakteristik permasalahan dalam transportasi ini dikategorikan kedalam vehicle routing problem (VRP) (Noon et al., 2019).

\section{Kapal}

Menurut Undang-Undang Nomor 17 Tahun 2008 tentang Pelayaran, "kapal" adalah kendaraan air dengan bentuk dan jenis tertentu, yang digerakkan dengan tenaga angin, tenaga mekanik, energi lainnya, ditarik atau ditunda, termasuk kendaraan yang berdaya dukung dinamis, kendaraan di bawah permukaan air, serta alat apung dan bangunan terapung yang tidak berpindah-pindah (Undang-Undang 17 Republik Indonesia, 2008). Menurut Keputusan Menteri Perhubungan nomor : KM 14 tahun 2002 (Bab I pasal I) Kapal adalah kendaraan air dengan bentuk dan jenis apapun yang di gerakkan dengan tenaga mekanik,tenaga angin atau ditunda termasuk kendaraan yang berdaya dukung dinamis, kendaraann dibawah permukaan air serta alat apung dan bangunan terapung yang tidak berpindah-pindah (keputusanmenteri-perhubungan-no-14-tahun-2002-

tentang-penyelenggaraan-dan-

pengusahaan-bongkar-muat-barang-daridan-ke-kapal.pdf, n.d.).

Berdasarkan rutenya, kapal dagang dapat dibagi menjadi tramper dan liner. Trammper adalah kapal dengan tujuan, rute, dan jadwal tidak tetap sedangkan Liner adalah kapal yang memiliki tujuan, rute, dan jadwal yang tetap. Adapun berdasarkan jenisnya, kapal dagang dapat dibagi menjadi : Convential Liner Vessel (Kapal Barang Biasa), dan Semi Container Pallet Vessel

Full Container Vessel (Kapal Peti Kemas), General Cargo Breakbulk Vessel, RoRo (Roll on, Roll off, Barges (Pengangkut Tongkang), Bulk Carrier (Pengangkut Muatan Curah), Tug Boat (Kapal Tunda), Offshore Supply Ship (Kapal Pemasok Lepas Pantai), dan Kapal Tanker

\section{METODE}

Menurut Prof. Dr. Sugiyono (2016) metode penelitian adalah cara ilmiah untuk mendapatkan data dengan tujuan dan kegunaan tertentu. Cara ilmiah yang dimaksud adalah kegiatan penelitian didasarkan pada ciri-ciri keilmuan, yaitu rasional, empiris, dan sistematis. Rasional 
berarti kegiatan penelitian itu dilakukan dengan cara-cara yang masuk akal, sehingga terjangkau oleh penalaran manusia. Empiris berarti cara-cara yang dilakukan oleh penalaran manusia, sehingga orang lain dapat mengamati dan mengetahui cara-cara yang digunakan. Sistem istilah proses yang digunakan dalam melampirkan penelitian itu menggunakan langkah-langkah tertentu yang bersifat logis (Sugiyono, 2016). Menurut Hamid Darmadi (2013) metode penelitian adalah suatu cara ilmiah untuk mendapatkan data-data dengan tujuan kegunaan tertentu. Berdasarkan pemaparan diatas dapat disimpulkan bahwa metode penelitian adalah suatu cara ilmiah untuk mmperoleh data dengan tujuan dan kegunaan tertentu (Hamid Darmadi, 2013).

Menurut Prof. Dr. Nana Syaodih Sukamdinata (2016:60), penelitian kualitatif adalah suatu penelitian yang ditujukan untuk mendeskripsikan dan menganalisa fenomena, peristiwa, aktivitas sosial, sikap, kepercayaan, presepsi, pemikiran orang secara individual maupun kelompok. Penelitian kualitatif mempunyai 2 (dua) tujuan utama, pertama menggambarkan dan mengungkapkan dan kedua menggambarkan dan menjelaskan (Sukmadinata Nana Syaodih, 2013). Menurut Moleong (2015), penelitian kualitatif adalah penelitian yang bermaksud untuk memahami fenomena tentang apa yang dialami oleh subjek penelitian, misalnya perilaku, persepsi, motivasi, tindakan-tindakan dan lain-lain. Secara holistik dengan cara deskriftif dalam bentuk kata-kata dan bahasa, pada suatu konteks khusus yang ilmiah dan dengan memanfaatkan metode ilmiah (Moleong,2005).

Pengertian penelitian deskriptif kualitatif yaitu penelitian berupa lisan atau tertulis dari seseorang yang telah melakukan pengamatan terhadap suatu masalah agar data-data pendukung dapat dipertanggung jawabkan kebenarannya. Ciri-ciri penelitian deskriftif kualitatif yaitu penelitiannya diambil dari data hasil wawancara. Penelitian deskriftif kualitatif bersifat terbuka, analisis dapat dilakukan setelah data terkumpul. Kemudian pengumpulan data secara deskriftif ditulis dalam bentuk laporan data berupa kata-kata dan gambar, tetapi tidak dalam bentuk angka. Dalam pembahasan, penulis berusaha memaparkan hasil dari semua studi dan penelitian mengenai berbagai hal yang diperoleh, baik hal-hal yang bersifat teori yang memuat berupa hal-hal yang bersifat praktis. Penggunaan aspek observasi atau pengamatan sangat berperan dalam penulisan penelitian ini.

Adapun jenis pendekatan penelitian ini adalah deskriptif. Menurut Prof. Dr. Sugiyono (2016), metode deskriptif adalah metode yang digunakan untuk menggambarkan atau menganalisa suatu hasil penelitian tetapi tidak digunakan untuk membuat kesimpulan yang lebih luas. Berdasarkan pengertian tersebut, metode deskriptif merupakan metode penelitian untuk membuat gambaran mengenai situasi atau kejadian yang ada (Sugiyono, 2016). Jadi dalam penelitian ini penulis menggunakan metode deskriptif kualitatif yang bertujuan untuk mengungkapkan fakta, keadaan, fenomena, variabel dan keadaan yang terjadi saat penelitian berjalan dan menyajikan data-data apa adanya sehingga penelitian mendapatkan hasil yang sebenarnya dan dapat mengungkapkan permasalahan yang terjadi dalam perusahaan.

\section{Fokus dan Lokus Penelitian Fokus Penelitian}

Fokus penelitian dilakukan ppada tanggal 30 Juli 2018 hingga 31 Juli 2019.

\section{Lokus Penelitian}

Lokasi penelitian adalah tempat dimana penelitian dilakukan. Penelitian ini dilaksanakan di PT. Cipta Samudera Shipping Line Surabaya yang beralamatkan di Jalan Perak Timur No. 104, Perak Timur, Pabean Cantian, Kota Surabaya, Jawa Timur, Indonesia. 


\section{Sumber Data Penelitian}

Sumber data dalam penelitian ini diperlukan untuk melakukan sebuah penelitian yang dimaksud sumber data adalah darimana data diperoleh atau semua informasi yang diperoleh penulis, baik dari yang merupakan benda nyata, sesuatu yang abstrak, maupun peristiwa yang terjadu pada waktu penelitian melakukan praktek darat. Data dapat dikelompokkan berdasarkan cara pengumpulannya, data dapat dibagi menjadi 2 (dua) yaitu primer dan data skunder. Data primer menurut Husein Umar (2014:42) adalah data yang didapat dari sumber pertama baik individu atau perorangan seperti hasil dari wawancara atau hasil pengisian kuesioner yang bisa dialkukan oleh peneliti. (Husein Umar, 2014). Sedangkan data sekunder adalah sumber data penelitian yang diperoleh peneliti secara tidak langsung melalui media perntara (diperoleh dan dicatat oleh pihak lain). (Indriantoro Nur and Bambang Supomo, 2014).

\section{Teknik Pengumpulan Data}

Dalam penyampaian hasil penelitian kedalam sebuah tulisan tentunya harus disusun secara sistematis sesuai dengan tujuan penelitian. Oleh sebab itu, teknik pengumpulan data yang dilakukan oleh peneliti adalah dengan cara: Interview (Wawancara), Observasi (Pengamatan), Dokumentasi (Documentation), dan Studi Pustaka (Library Research)

\section{Metode Analisis Data}

Mengenai pengertian analisa data dan diantaranya yaitu analisis data kualitatif, Bogdan dan Biklen memberikan pengertian bahwa analisis data kualitatif adalah upaya yang dilakukan dengan jalan bekerja dengan data, mengorganisasikan data, memilah-milahnya menjadi satuan yang dapat dikelola, mensintesiskannya, mencari dan menemukan pola menemukan apa yang penting dan apa yang dipelajari, dan memutuskan apa yang perlu diceritakan kepada orang lain (Moleong, 2005).
Dalam analisis data kualitatif akan menghasilkan data deskriptif. Pada penulisan ini, penulis juga menggunakan analisis deskriptif yaitu dengan menjelaskan dan menceritakan perincianerincian yang penulis dapatkan selama melakukan penelitian di PT. Cipta Samudera Shipping Line Surabaya. Data yang dilakukan penulis meliputi: Reduksi Data, Penyajian Data, dan Menarik Kesimpulan.

\section{HASIL DAN PEMBAHASAN Analisis Masalah}

Noon report adalah lembar data yang disiapkan oleh chief engineer kapal setiap hari. Laporan ini memberikan posisi kapal dan data standar lainnya yang relevan untuk menilai kinerja kapal berdasarkan kecepatan dan kekuatan lingkungannya termasuk kondisi cuaca. Noon report kapal memuat informasi mengenai lokasi kapal, pelabuhan asal, pelabuhan yang dituju, daily activity, kondisi kapal, cuaca, Time Departure (TD) atau yang di sebut waktu pemberangkatan kapal, dan Estimate Time Arrival (ETA) atau waktu kapal tiba. Informasi mengenai ETA sangat penting bagi agent kapal untuk membooking pilot di atas kapal serta dermaga yang akan digunakan, selain itu ETA juga digunakan untuk proses ke imigrasian jika kapal berlayar antar negara serta untuk laporan harian kepada kantor atau perusahaan saat kapal itu berlayar(Noon et al., 2019). Noon report dapat digunakan sebagai acuan untuk perhitungan komponen biaya yang di keluarkan oleh kapal, keterlambatan pengiriman noon report bisa menunda staff manajemen darat dalam melakukan perhitungan komponen biaya dan hal tersebut bisa menyebabkan kerugian terhadap biaya operasional. Karakteristik permasalahan dalam transportasi ini dikategorikan kedalam vehicle routing problem (VRP) (Noon et al., 2019).

Dalam penelitian yang dilakukan oleh peneliti selama melaksanakan praktek darat dengan judul "Analisis Keterlambatan Noon report Kapal Mt. Cipta Anyer Pada 
PT. Cipta Samudera Shipping Line" mendapatkan beberapa hasil penelitian terkait dengan tiga rumusan masalah yang dirumuskan oleh peneliti. Ketiga rumusan masalah tersebut antara lain: (1) Apakah yang menyebabkan keterlambatan noon report kapal MT. Cipta Anyer pada PT. Cipta Samudera Shipping Line; (2) Apakah dampak yang ditimbulkan akibat keterlambatan noon report kapal MT. Cipta anyer pada PT. Cipta Samudera Shipping Line; (3) Bagaimanakah upaya yang harus dilakukan guna mengatasi keterlambatan noon report kapal MT. Cipta Anyer pada PT. Cipta Samudera Shipping Line?. Dalam penelitian ini penulis menemukan hasil penelitian yang didapatkan dari wawancara, observasi, dokumentasi dan studi pustaka.

\section{Apakah yang menyebabkan keterlambatan noon report kapal MT. Cipta Anyer pada PT. Cipta Samudera Shipping Line?}

Berdasarkan penelitian yang dilakukan oleh peneliti terkait dengan penyebab keterlambatan noon report MT. Cipta Anyer pada PT. Cipta Samudera Shipping Line, terdapat beberapa penyebab keterlabatan. Hasil penelitian tentang penyebab keterlambatan tersebut sebagian besar diperoleh dari wawancara terhadap dua narasumber. Dari ketiga metode pengumpulan data yang digunakan peneliti untuk mendapatkan hasil penelitian.

1. Tidak ada SOP yang mengatur secara detail tentang noon report

Berdasarkan dokumentasi yang dilakukan peneliti tentang pemberlakuan standar operasional prosedural tentang pelaksanaannoon report. Tidak ditemukan standar operasional prosedural yang mengatur tentang pengiriman noon report beserta kebijakan terhadap keterlambatan pengirimannya. Sedangkan pemberian SOP tentang pengiriman noon report beserta kebijakan terhadap keterlambatan pengirimannya berpengaruh terhadap kelancaran pengiriman noon report. Tanpa SOP dan penerapan SOP yang terlaksana secara teratur, maka kinerja tidak dapat terlaksana secara maksimal. Dari hasil penelitian tersebut peneliti melakukan penarikan kesimpulan bahwa tidak adanya SOP yang mengatur secara detail tentang noon report merupakan salah satu faktor penyebab keterlambatan noon report kapal MT. Cipta Anyer pada PT. Cipta Samudera Shipping Line

2. Pengiriman noon report melebihi batas waktu yang telah ditentukan

Berdasarkan wawancara yang dilakukan oleh peneliti, terdapat beberapa kali keterlambatan pengiriman noon report / laporan malam dari anak buah kapal ke perusahaan. Keterlambatan yang paling lama dari waktu pengiriman yang seharusnya adalah 10 hari lebih tepatnya yang seharusnya dikirim pada tanggal 29 Mei 2019 baru di kirim pada yang tanggal 8 Juni 2019. Lebih lanjut lagi responden menjelaskan keterlambatan tersebut dapat diatasi denganmelaksanakan pengiriman dengan menyertakan laporan-laporan yang belum dikirim sekaligus.Selain itu pula terdapat anak buah kapal yang baru sign on di atas kapal. Anak buah kapal tersebut on board pada tanggal 26 Juni 2019. Dari keterangan yang diberikan oleh responden, anak buah kapal tersebut tidak diberikan trainning tentang noon report terlebih dahulu. Sedangkan trainning, sosialisasi, serta familiarisasi termasuk yang terkait dengan noon report merupakan kegiatan penting yang harus diberikan kepada ABK ketika akan melaksanakan kerja di atas kapal untuk menghindari keterlambatan pengiriman noon report. Akibat dari hal ini ABK yang tidak mendapat training tentang sebelum on board tersebut mendapat kendala pada saat membuat noon report.

Selain itu berdasarkan observasi yang dilakukan oleh peneliti tentang keterlambatan akibat penyelesaian 
pengisian hingga pengiriman noon reportyang melebihi batas waktu oleh anak buah kapal, terdapat perbedaan ketepatan waktu pengiriman antara anak buah kapal yang tergolong menguasai teknologi dengan yang tidak menguasai teknologi. Hal ini dilakukan dengan pelaksanaan observasi serta dokumentasi dengan membandingkan pemahaman teknologi anak buah kapal dengan indikator pembeda antara lain: usia serta pengalaman kerja. Indikator tersebut digunakan sebagai alat bantu untuk membandingkan pemahaman anak buah kapaltentang teknologi terhadap ketepatan waktu pengisian noon report sampai dengan terkirimnya noon report. Dari hasil penelitian tersebut peneliti menarik kesimpulan bahwa keterlambatan akibat penyelesaian pengisian hingga pengiriman noon reportyang melebihi batas waktu oleh anak buah kapal merupakan salah satu faktor penyebab keterlambatan noon report kapal MT. Cipta Anyer pada PT. Cipta Samudera Shipping Line.

3. Koneksi internet yang tidak stabil

Berdasarkan penelitian yang dilakukan peneliti selama melaksanakan praktek darat, pernah terjadi keterlambatan pengiriman noon report akibat terputusnya koneksi internet. Hal ini disebabkan data kuota internet yang tidak mencukupi sehingga pengiriman noon report tidak dapat dilaksanakan. Akibatnya pengiriman noon report terlambat hingga 3 hari dari waktu pengiriman. Hal ini cukup mempengaruhi ketepatan waktu dari pengiriman noon report sehingga perhatian perusahaan terkait koneksi internet yang digunakan untuk melaksanakan pengiriman internet akan mempengaruhi ketepatan waktu pengiriman noon report. Dari hasil penelitian tersebut peneliti melakukan penarikan kesimpulan bahwa keterlambatan pengiriman noon report akibat koneksi internet yang terputus merupakan salah satu faktor penyebab keterlambatan noon report kapal MT. Cipta Anyer pada PT. Cipta Samudera Shipping Line.

\section{Apakah dampak yang ditimbulkan akibat keterlambatan noon report kapal MT. Cipta Anyer pada PT. Cipta Samudera Shipping Line?}

Berdasarkan penelitian yang dilakukan oleh peneliti terdapat beberapa dampak yang ditimbulkan akibat keterlambatan noonreport kapal MT. Cipta Anyer pada PT. Cipta Samudera Shipping Line antara lain:

1. Terhambatnya staff finance dalam membuat laporan bulanan.

Berdasarkan hasil wawancara yang dilakukan kepada responden, dampak yang ditumbulkan akibat keterlambatan noon report kapal MT. Cipta Anyer pada PT. Cipta Samudera Shipping Line salah satunya yaitu terhambatnya staff finance dalam membuat laporan bulanan. Dalam wawancara tersebut kedua responden menyebutkan hal yang serupa yang pada intinya keterlambatan pengiriman noon report tersebut mengakibatkan terhambatnya staff finance dalam membuat laporan bulanan. Lebih rinci dijelaskan juga bahwa keterlambatan pengiriman noon report dapat mengakibatkan penumpukan dokumen serta kerja yang lebih banyak pada satu tertentu untuk melakukan laporan rutin sedangkan hal tersebut dapat diatasi dengan dilakukan secara teratur sehingga tidak menumpuk. Selain itu juga berdampak pada terhambatnya perhitungan operasional kapal seperti perhitungan bahan bakar, perhitungan ETA kapal, perhitungan kecepatan yang dibutuhkan dari pelabuhan ke pelabuhan, serta perhitungan kelayakan kapal untuk beroperasi atau layak laut.

Selain itu berdasarkan observasi yang dilakukan oleh peneliti, terdapat kesamaan dampak yang ditimbulkan akibat terhambatnya pengiriman noon 
reportsalah satunya adalah terhambatnya pelaksanaan kinerja administratif di perusahaan. Terhambatnya pelaksanaan kinerja administratif tersebut didasarkan pada terhambatnya pengiriman laporan rutin. Laporan rutin tersebut terdiri dari laporan tiga bulanan, enam bulanan, serta laporan akhir tahun. Hal ini cukup merugikan baik secara waktu, tenaga, serta kerugian akibat terhambatnya staff finance dalam membuat laporan bulanan.

Dari hasil penelitian tersebut dapat disimpulkan bahwa keterlambagan pengiriman noon report akan berdampak pada terhambatnya staff finance dalam membuat laporan bulanan.

2. Kinerja perusahaan menjadi tidak optimal

Adanya keterlambatan dalam laporan bulanan dan penumpukan dokumen menjadikan kinerja perusahaan tidak optimal yang mana seharusnya laporan dan dokumen kerja sudah tersusun dalam pengerjaannya menjadi tidak beraturan sehingga karyawan yang menangani menjadi kewalahan dan membuat sistem kerja menjadi tidak beraturan. Dengan demikian perusahaan tidak dapat mengatasi keterlambatan ini sehingga tidak satu jalan dengan visi dan misi perusahaan.

3. Menyebabkan kerja extra terhadap perwira kapal yang bertanggung jawab dalam pengiriman noon report.

Dalam wawancara yang dilakukan peneliti kepada anak buah kapal dampak yang ditimbulkan akibat keterlambatan pengiriman noon reportadalah penumpukan noon reportyang belum terkirim sehingga perwira kapal yang bertanggung jawab terhadap pengiriman noon report harus melakukan kerja extra untuk menyusun dan membuat laporan noon reportbaik noon reportpada hari tersebut maupun noon report pada hari sebelumnya yang belum dilaporkan. Dari hasil penelitian tersebut peneliti melakukan penarikan kesimpulan bahwa menyebabkan kerja extra oleh perwira yang bertanggung jawab dalam pengiriman noon report merupakan salah satu dampak yang ditimbulkan akibat keterlambatan noon report kapal MT. Cipta Anyer pada PT. Cipta Samudera Shipping Line

\section{Bagaimanakah upaya yang harus dilakukan guna mengatasi} keterlambatan noon report kapal MT. Cipta Anyer pada PT. Cipta Samudera Shipping Line?

1. Memberikan trainnning tentang pengiriman noon report untuk menghindari keterlambatan

Berdasarkan wawancara yang dilakukan peneliti kepada responden, kedua responden memberikan keterangan tentang salah satu upaya yang harus dilakukan guna mengatasi keterlambatan noon report adalah memberikan training kepada anak buah kapal baru sebelum bekerja diatas kapal. Hal ini cukup berkaitan terhadap salah satu penyebab keterlambatan pengiriman noon report yakni terdapat anak buah kapal yang tidak mendapat trainning terlebih dahulu sehingga mengakibatkan terlambatnya noon report untuk di kirim ke perusahaan.

2. Melakukan evaluasi antara staff perusahaan dengan anak buah kapal terkait keterlambatan noon report.

Berdasarkan wawancara kepada responden, salah satu upaya yang dapat dilakukan untuk mengatasi keterlambatan noon report kapal MT. Cipta Anyer pada PT. Cipta Samudera Shipping Line adalah memberikan evaluasi antara staff perusahaan dengan anak buah kapal terkaitnoon report untuk mengirimkan noon report secara tepat waktu.

Selain hasil wawancara tersebut, berdasarkan observasi yang dilakukan peneliti selama melaksanakan praktek 
darat salah satu upaya yang dapat dilakukan untuk mengatasi keterlambatan noon report kapal MT. Cipta Anyer adalah memberikan evaluasi dan teguran kepada anak buah kapal apabila terjadi keterlambatan pengiriman noon report. Hal ini didasarkan ketika anak buah kapal diberikan teguran oleh staff kantor terdapat perubahan yaitu anak buah kapal lebih cepat atau lebih tepat waktu dibandingkan sebelum ditegur oleh pihak staff perusahaan.

Dari hasil penelitian tersebut peneliti menarik kesimpulan bahwa salah satu upaya yang harus dilakukan dilakukan guna mengatasi keterlambatan noon report kapal MT. Cipta Anyer pada PT. Cipta Samudera Shipping Lineadalah melakukan evaluasi antara staff perusahaan dengan anak buah kapal terkait keterlambatan noon report.

3. Menyediakan koneksi internet yang memadai.

Berdasarkan wawancara yang dilakukan oleh peneliti kepada dua responden, kedua responden memberikan keterangan yang pada intinya menjurus untuk menyediakan koneksi internet yang memadai agar tidak terjadi keterlambatan saat mengirimkan noon report. Hal ini sejalan dengan salah satu penyebab terkendalanya pengiriman noon report yang pernah terjadi yaitu akibat terputusnya koneksi internet akibat data kuota internet yang tidak mencukupi sehingga dapat dilakukan upaya dengan menyediakan koneksi internet yang memadai.

Selain itu berdasarkan wawancara yang dilakukan peneliti kepada anak buah kapal tentang upaya yang dapat dilakukan guna mengatasi keterlambatan noon reportsalah satunya dengan menyediakan koneksi internet yang memadai untuk menghindari keterlambatan pengiriman yang disebabkan oleh terputusnya atau terhambat oleh sinyal internet diatas kapal. Dari hasil penelitian tersebut peneliti melakukan penarikan kesimpulan bahwa menyediakan koneksi internet yang memadai merupakan salah satu upaya yang harus dilakukan guna mengatasi keterlambatan noon reportkapal MT. Cipta Anyer pada PT. Cipta Samudera Shipping Line.

\section{KESIMPULAN \& SARAN \\ Kesimpulan}

Kesimpulan yang diperoleh dari kajian penelitian ini adalah sebagai berikut:

1. Penyebab keterlambatan noon report kapal MT. Cipta Anyer pada PT. Cipta Samudera Shipping Line ialah tidak adanya SOP yang mengatur secara detail tentang noon report, pengiriman noon report melebihi batas waktu yang telah ditentukan, dan koneksi internet yang tidak stabil.

2. Dampak yang ditimbulkan akibat keterlambatan noon report kapal kapal MT. Cipta Anyer pada PT. Cipta Samudera Shipping Line antara lain adalah menghambat kinerja staff finance, kinerja perusahaan menjadi tidak optimal,dan menyebabkan kerja extra terhadap perwira yang bertanggung jawab dalam pengiriman noon report.

3. Upaya yang harus dilakukan guna mengatasi keterlambatan noon report kapal MT. Cipta Anyer pada PT. Cipta Samudera Shipping Line antara lain adalah memberikan trainning mengenai pengiriman noon report untuk menghindari keterlambatan, melakukan evaluasi anatara staff perusahaan dengan anak buah kapal terkait keterlambatan noon report, dan menyediakan koneksi internet yang memadai.

\section{Saran}

Dalam kajian ini, peneliti menambahkan saran yang berhubungan dengan keterlambatan noon report kapal MT. Cipta 
Anyer pada PT. Cipta Samudera Shipping

Line antara lain:

1. PT. Cipta Samudera Shipping Line sebaiknya membuat SOP yang mengatur tentang noon report agar menjadi lebih sistematik dan tidak menghambat laporan bulanan staff finance.

2. PT. Cipta Samudera Shipping line sebaiknya menyediakan fasilitas internet yang lebih memadai agar dapat memperlancar pengiriman noon report.

3. PT. Cipta Samudera Shipping Line sebaiknya memberikan trainning tentang noon report kepada crew kapal yang baru sebelum bekerja agar dapat menjalankan tugasnya sesuai dengan tugas dan tanggung jawabnya

\section{DAFTAR PUSTAKA}

Ervianto, I. W. 2005. Manajemen Proyek Konstruksi Edisi Revisi. Yogyakarta: Andi.

Hamid Darmadi. 2013. Metode Penelitiann Pendidikan dan Sosial. Bandung: Alfabeta, CV.

Husein Umar. 2014. Metode Penelitian Untuk Skripsi dan Tesis Bisnis. Edisi-

2. Cetakan ke-13. Jakarta: Rajawali Pers.

Indriantoro Nur and Bambang Supomo. 2014. Metodologi Penelitian Bisnis UNtuk Akuntansi dan Manajemen. Edisi 1. Cetakan ke-12. Yogyakarta: BPFE.

Keputusan-menteri-perhubungan-no-14- tahun-2002-tentang-penyelenggaraandan-pengusahaan-bongkar-muatbarang-dari-dan-ke-kapal.pdf. (n.d.).

Moleong. 2005. Metode Penelitian Kualitatif. Bandung: PT. Remaja Rosdakarya.

Noon, B., Kapal, R., Xx, P. T., \& Prasetyawati, D. 2019. Penerapan Voyage Account. 2(April), 31-37.

Okvita, Y. 2013. Promotif, Preventif, Kuratif, Rehabilitatif. Retrieved from http://yunivia88.blogspot.co.ic/2013/0 5/promotifpreventifkuratifrehabilitatif. html

Sailor, I. (n.d.). Tugas dan Tanggung Jawab 2nd Officer. Retrieved from https://indonesiansailor.blogspot.com/2017/12/tugasdan-tangggung-jawab-2nd-officer.html

Sugiyono. 2016. Metode Penelitian Kuantitatif, Kualitatif dan $R \& D$. Bandung: PT Alfabet.

Sukmadinata Nana Syaodih. 2013. Metode Penelitian Pendidikan. Bandung: PT. Remaja Rosdakarya.

Suprapto. 2019. Jabatan Pelaut Di Atas Kapal : Perwira Deck dan Tugasnya. Retrieved from https://www.kamuspelaut.com/2019/0 6/mengenal-perwira-deck-dantugasnya.html

Undang-Undang 17 Republik Indonesia. 2008. UU 17 tahun 2008 tentang Pelayaran. The Visual Computer, 24(3), 155-172. 